\title{
Escaping Populism - Safeguarding Minority Rights: Non-Majoritarian Dynamics in European Policy-Making
}

\author{
Eiko Thielemann and Natascha Zaun
}

(Date of acceptance: 2 September 2017, Journal of Common Market Studies)

\begin{abstract}
Contrary to earlier predictions, communitarization in the area of asylum policies has not led to an erosion of refugee rights. Instead, there is growing evidence that EU asylum harmonization has safeguarded existing standards and even enhanced the rights of asylum-seekers and refugees in Europe. We seek to explain this by building on the insights of principal-agent theory. We argue that delegation to supranational institutions can strengthen non-majoritarian policy dynamics and shield EU policy-makers from populist pressures for further immigration restrictions that national governments are often confronted with. We support this argument empirically through a systematic longitudinal analysis of the evolution of EU asylum policies. In particular, we seek to assess the motivation for and impact of greater delegation to EU institutions on rights developments for asylum-seekers and refuges. We also explain to what extent EU policymaking has changed with the EU's response to the 'Syrian refugee crisis'.
\end{abstract}

Key words: Asylum, European Union Institutions, Justice and Home Affairs, Minority Rights, Populism, Principal-Agent Theory

\section{EU asylum cooperation and the rights of refugees in Europe}

Immigration and asylum matters have long been critically observed by the public. In the UK's referendum on the European Union (EU), they were highly politicised by supporters of the leave campaign, who fuelled strong anti-immigrant attitudes present among large parts of the electorate, arguing that leaving the EU would stop uncontrolled immigration to the UK (Dathan, 2016). But this of course is not just a British phenomenon. Across the EU large parts of the electorate favour a decrease in immigration, which makes even moderate parties from across the political spectrum adopt anti-immigrant positions (Alonso and Claro da Fonseca, 2012, p. 867). Given widespread public resentment, policy-makers face a dilemma as the logic of majoritarian politics calling for further restrictions often stands in contrast to the basic human rights obligations of liberal states, particularly those concerning the protection of refugees. Historically, non-majoritarian institutions, such as national courts, have provided a counterweight to populist pressures for restricting minority rights and played an important role in safeguarding states' adherence to basic human rights of migrants (Joppke, 2001). 
The rise of EU co-operation has been viewed by many as threatening that role (e.g. Fry, 2005; Hathaway, 2003). It has been argued that EU policy-making has strengthened the role of the executive, reduced accountability and limited judicial oversight in European policy-making. Some have even viewed the EU level as a strategic venue chosen by those who want to adopt more restrictive policies across Europe (Guiraudon, 2000). Recent developments such as the 2016 EU-Turkey Statement on the return of forced migrants to Turkey have again highlighted such concerns.

When assessing the broader impact of the EU, predictions about an EU-induced erosion of migrants' rights increasingly seem at odds with the empirical reality. Studies point to numerous examples where adopting common standards has necessitated legislative changes and the adoption of rights-enhancing policies in the Member States (Kaunert, 2009; Kaunert, 2010; El-Enany and Thielemann, 2011; Kaunert and Léonard, 2012; Zaun, 2016, 2017). However, theoretical attempts to explain such dynamics have, with notable exceptions (Kaunert, 2009, 2010; Kaunert and Léonard, 2012; Zaun, 2016, 2017), remained limited. Zaun (2016; 2017), for instance, argues that liberalizations during the first phase of the Common European Asylum System (CEAS) can be explained by the dominance of 'strong regulators' (i.e. states with a long regulatory tradition in the field and a well-functioning administration) trying to impose their standards on 'weak regulators'. However, this argument is unable to explain standards exceeding the lowest common denominator of the strong regulators. Kaunert $(2009,2010)$ and Kaunert and Léonard (2012) have argued that the EU's technocratic and legalistic approach can account for EU asylum policy liberalization. Yet, it remains puzzling why Member States with their alleged restrictive preferences would delegate to institutions that produce policies at odds with these preferences.

This article draws on the principle-agent literature to advance our theoretical understanding of the motivation and the consequences of delegating asylum policymaking to EU institutions. It argues that by delegating agenda-setting, decision-making and implementation in the area of asylum to EU institutions (the agents), national governments (the principals) strengthen non-majoritarian policy dynamics that shield European policy-makers from some of the populist pressures that national governments face (Thatcher and Stone Sweet, 2002, p. 2). We therefore expect more non-majoritarian policy dynamics to promote more liberal (less restrictive) standards. Hence, the more communitarized EU asylum policies are, the more likely they will safeguard or strengthen 
minority rights. The concepts of non-majoritarian and majoritarian institutions are best understood as two ends of a continuum rather than two clearly distinguishable alternatives. The European Commission and the Court of Justice of the European Union (CJEU) are certainly the least subject to electoral pressures among the EU institutions. ${ }^{1}$ The European Parliament (EP) takes a middle-ground position. As an elected body, the EP is per definition a majoritarian institution. Yet, when speaking of non-majoritarian institutions, we focus on their separation from anti-immigrant attitudes existing in the wider national electorate. Arguably, the EP is much better shielded from populist pressures than national parliaments, and its greater distance from voters has long been subject to criticism (see Marquand, 1979, p. 64 on 'democratic deficit'). Not only is the turnout of voters substantially lower than in national elections, political parties in the EP also represent a variety of cleavages, as they are composed of parties from Member States that share limited communalities. Being composed of representatives from national ministries, the Council is certainly the 'most majoritarian' among the EU institutions. Yet, working in a less transparent and more complex institutional environment, the Council's decisions are under less severe scrutiny than national government decisions, which enables the Council to shift blame for unpopular policies to Brussels.

Empirically, we support our argument through a comparative analysis of EU asylum standards before and after the introduction of ordinary legislative procedure. This assessment will be complemented with a discussion about the extent to which nonmajoritarian policy dynamics and their rights-enhancing effects have been challenged by the EU's response to the 2015 'Syrian Crisis'.

\section{Escaping populism through delegation: the role of non-majoritarian politics in EU policy-making}

\section{Motivation for delegation}

'Principal-agent' theory and its application to the EU (Pollack, 1997, p. 103-104; Thatcher and Stone Sweet, 2002, p. 4) suggest two types of motivation for delegation which are important in the area of asylum: enhancing the credibility of commitments and enabling unpopular decisions such as the protection of minority rights which are often

\footnotetext{
${ }^{1}$ While the European Court of Human Rights (ECtHR) is not directly part of the EU architecture, delegation to this court can also have an important impact on asylum policy-making, as the CJEU and the ECtHR have been demonstrated to cross-reference each other on a regular basis in different areas of EU policy-making (Jacobs, 2003).
} 
underrepresented in majoritarian systems. It has been persuasively argued that, first, delegation can limit free-riding opportunities by enhancing the credibility of a commitment, and second, that it allows policy-makers to escape the 'diktat' of the majority and the short-term focus that often characterises policies emerging from majoritarian institutions adhering to the logic of electoral cycles (Thatcher and Stone Sweet, 2002, p. 4 \& p. 9-10).

Thatcher and Stone Sweet (2004, p. 4) also highlight that principals establish agents to resolve problems of commitment in the case of collective action problems, e.g. between multiple principles. Delegation in the EU context is therefore not necessarily a symmetrical process, initiated by all Member States to the same extent. Instead, those Member States that have the impression that others are free-riding use delegation to prevent them from doing so. Moreover, delegation provides 'principals' with opportunities to escape populist pressures and legislate on controversial issues, such as asylum policy. Thus, they can avoid paying the electoral price that legislation in this area often implies for moderate parties, given the widespread restrictive preferences of the electorate (Alonso and Claro da Fonseca, 2012; Howard, 2010) and the fact that populist parties are always ready to adopt more restrictive positions. Due to the restrictive preferences of the electorate, policy-makers will feel forced to adopt restrictive policies, even if this risks bringing their country into conflict with its obligations under international law. This is particularly the case when right-wing populist parties hold a significant part of the electorate (Howard, 2010, p. 744). Delegation provides national policy-makers with additional leeway, as policy outcomes at the EU level will not be immediately associated with them and even enable them to blame 'Brussels' for unpopular decisions.

\section{The expected impact of delegation}

In the case of European asylum policies, delegation to EU institutions can be expected to safeguard protection standards for asylum-seekers by isolating European policy-making from populist pressures at home. This, of course, follows partly from the motivation for delegation. However, EU institutions have also been demonstrated to engage in 'bureaucratic drift', promoting positions that are different from those of their principals (Pollack, 1997, p. 108; Burley and Mattli, 1993). Therefore, it is also possible that the EU institutions (the agents) adopt positions that are more pro-integrationist and more liberal than Member States could subscribe to. 
When the decision-making rules are more supranational, the influence of nonmajoritarian institutions like the Commission can be expected to be greater. Hence one would expect higher (less restrictive) standards the more supranational (communitarized) these rules are.

European migration governance has been fundamentally transformed over the past three decades. Today's governance rules for asylum matters under the Lisbon Treaty operate under the same supranational arrangements existing for the most integrated parts of the EU project, i.e. the Single Market. Through delegation, we can expect an increasing influence of the (more) liberal preferences of 'supranational agents' on policy outcomes at all three stages of the policy-making process: agenda-setting, decision-making, and policy implementation.

The Commission now holds the monopoly of legislative initiatives and has enhanced its influence as decisions in the Council are taken by qualified majority voting (and no longer by unanimity) (Pollack, 1997, p. 106). The EP is a co-legislator with full veto powers and the CJEU has the authority to adjudicate over both the making and the implementation of EU policies. Delegation can also limit discretion and non-compliance during implementation as EU institutions can help with the 'completion of incomplete contracts' and provide independent oversight. As Burley and Mattli (1993) have shown, delegation to the CJEU can play a crucial role in narrowing implementation gaps. With the Lisbon Treaty, Member States have extended the delegation of powers to the CJEU. No longer is the preliminary reference procedure limited to national courts or last instance courts, but instead it is now available to all national courts (House of Lords European Union Committee, 2008, p. 125-26). Judicial activism likely further strengthened the impact of these newly delegated powers.

Of course, the increased powers of non-majoritarian institutions do not imply that the Council has become a marginal actor in EU asylum policy-making. However, ceteris paribus non-majoritarian institutions are likely to have a stronger impact in the second phase than in the first phase of the CEAS, given the more communitarised decisionmaking mode applied. As their positions are more liberal than those of the Council, policy outputs are therefore likely to be more liberal. 


\section{Why Member States have delegated asylum policy-making to the EU}

Member States have opted for delegation to EU institutions in asylum policy-making for two reasons. First, they deployed delegation to limit dynamics of 'responsibility-shifting'. While previous cooperation in a purely intergovernmental setting already tried to overcome these dynamics, it was not able to achieve this goal, because commitments could not be enforced (Stetter, 2000). Second, through delegating to the technocratic EU decision-making environment, asylum policies, which have often been exploited by rightwing populist parties (Rydgren, 2004), are being depoliticised.

Responsibility-shifting follows from collective action problems in refugee protection. According to Suhrke (1998) the security gains resulting from refugee protection have some characteristics of a non-excludable public good. States therefore have an incentive to free-ride on others. As refugee protection involves costs, states adopt restrictive policies to encourage asylum-seekers to seek protection elsewhere. In the EU, this can lead to a regulatory 'race to the bottom' as Member States adopt more restrictive policies to become less attractive to asylum-seekers relative to other Member States (Thielemann, 2006). These dynamics could be observed before asylum policies were delegated to the EU. In the 1990s, Northern European Member States received the largest share of asylum- seekers in Europe. To curb free-riding and to advance a more equitable sharing of refugee responsibilities across Europe, these states had an interest in enhanced communitarization. Germany was a particularly fervent supporter of harmonization and quota-based responsibility-sharing mechanisms at the EU level during the negotiations of the Maastricht Treaty and the early negotiations of the Amsterdam Treaty. However, when asylum applications started to decline again, Germany's enthusiasm for further delegation to the EU also cooled. During the negotiations of the Constitutional Treaty (that ultimately resulted in the Lisbon Treaty), Germany blocked full harmonization, while the UK became the main supporter of greater delegation at the time as its numbers of asylum applications were the highest in Europe (Zaun 2017, p. 67). As soon as applications to the UK declined again, it lost interest in enhanced EU cooperation and even opted out of much of the second phase of the CEAS (Thielemann and El-Enany, 2013, p. 220).

The analysis of the negotiations of EU asylum instruments over the years support the argument that greater delegation to the EU was perceived to limit free-riding by preventing Member States from encouraging secondary movements through unilateral policy restrictions. This logic was effectively summarised in a Council discussion paper 
on the reception conditions directive in which the French delegation promoted greater EU policy harmonization, suggesting that the "[t]he disparity between reception arrangements in Europe makes certain Member States more attractive than others for asylum applicants. Harmonization in this respect would reduce these secondary movements [...]" (Council of Ministers, 2000a).

The desire of national politicians to de-politicise refugee policy-making in order to lower the 'temperature' of the domestic debates on asylum and to prevent populist parties from exploiting the issue has been another motivation for delegation that can be supported through evidence. In the case of Germany, for instance, asylum was a hotly debated issue in the early 1990s and populism fuelled multiple attacks on immigrants. There was thus strong consensus among policy-makers to avoid new legislative debates on asylum. According to a well-placed observer of the German debates at the time, politicians know that asylum and migration policies "are perfect topics to lose an election with, if you are not careful" or more specifically "topic[s] that can cost moderate parties their head, because they cannot convince the voter [...], whilst populist parties are [...] strengthened” (Interview, Think Tank 1). A former official from the German Interior Ministry confirms: “After arsons directed against refugee reception centres in 1992/1993 [...] politicians had a strong interest in asylum policies not being discussed publicly again" (Interview, Interior Ministry_DE). Another example supports our assumption that policy-makers mainly fear punishment by an anti-immigrant electorate. When asked about the reason why Member States de jure maintain a highly inefficient distribution mechanism (Dublin III) which is no longer applied in practice, they respond that Dublin has mainly symbolic functions and should signal the electorate that policy-makers keep tight control over refugee inflows (Interview, Consultant). The EU was considered an attractive alternative venue to the national arena, because EU policy-making processes were more obscure, technical, and de-politicized.

\section{The impact of non-majoritarian dynamics on European asylum standards}

To empirically assess the impact of non-majoritarian dynamics, we will, first, compare the three principal legal instruments developed during the first phase of the CEAS between 2000 and $2005^{2}$ with their 'recasts' during the second CEAS phase from 2008 until 2013. ${ }^{3}$

\footnotetext{
2 These are the Reception Conditions Directive (Council Directive 2003/9/EC of 27 January 2003), the Qualification Directive (Council Directive 2004/83/EC of 29 April 2004) and the Asylum Procedures Directive (Council Directive 2005/85/EC of 1 December 2005).
} 
The first and the second phase of the CEAS are 'most similar cases' (cf. Seawright and Gerring, 2008, p. 304-306), except for the decision-making procedures, which are only partly communitarized in the first phase of the CEAS but fully communitarized in its second phase. This represents the design of a 'natural experiment' and allows us to hold all variables constant except for the one under investigation, namely the strengthened competences of non-majoritarian institutions through increased delegation. Focusing on the Reception Conditions Directive, we then trace the role of non-majoritarian dynamics on policy outputs at the EU level (policy on paper). In this context, we first study the agenda-setting role of the Commission and the CJEU as well as the influence of the EP. Second, we look into the Commission's and the CJEU's role in holding Member States accountable in the implementation process (policy in practice).

\section{Comparing policy output on the three core directives}

Comparing the policy output in the three core directives across the two periods, we find rights enhancements on most policies (cf. Table 1). The Reception Conditions Directive is now applied to all applicants (scope), including those that are subject to procedures under the Dublin Regulation and accelerated or border procedures. The special reception needs of vulnerable applicants are to be accounted for and an exhaustive list on detention grounds is introduced prohibiting arbitrary detention or detention on other grounds. Access to work is now permitted after nine months instead of twelve months in the original directive. Lastly, the directive introduces limits for the grounds on which Member States may set different modalities for material reception conditions, requiring access to health care and a dignified living standard even where material reception conditions are reduced and withdrawn, while no longer considering late submission of an application as a ground for the refusal of reception conditions. The special needs of vulnerable applicants are now also to be recognised.

The family definition of the Qualification Directive is extended and minor children of international protection beneficiaries are no longer explicitly required to be dependent. In the definition of actors of protection, a requirement is introduced that such protection needs to be effective and non-temporary and the internal protection alternative is only applied if the person can settle there, not withstanding technical obstacles. The rights of refugees and beneficiaries of subsidiary protection are furthermore aligned and gender

\footnotetext{
3 These are the recast reception conditions directive 2013/33/EU of the European Parliament and of the Council of 26 June 2013, the recast Qualification Directive 2011/95/EU of the European Parliament and the Council of 13 December 2011 and the recast Asylum Procedures Directive of 2013/32/EU of the European Parliament and of the Council of 26 June 2013.
} 
and gender identity are criteria to be accounted for when assessing membership of a 'particular social group'.

Following the Procedures Directive asylum-seekers should have access to a procedure with clear deadlines for the registration of the asylum apllication. In addition to free legal aid in case of negative decisions provided by the original Procedures Directive, the recast directive grants free legal aid at first instance procedures. Moreover, it strengthens access to an effective remedy by establishing the right to a full and ex nunc examination of facts, requiring courts to base their judgment not only on facts established during the first instance procedure but also to consider new relevant information. The legislative output on the personal interview is rather mixed. On the one hand, the possibility to omit it is now limited to cases where a positive decision can be taken or where the applicant is considered unable to be interviewed. On the other hand, the possibility to temporarily involve personnel of another authority is introduced to account for times of a high volume of applications, which risks involving inadequately trained personnel. Additionally, the right to remain in case of subsequent applications is further limited in cases where no additional information substantiating the claim is submitted and where the subsequent claim is made "merely in order to the delay or frustrate the enforcement of a decision" (art. 41 para. 1 lit. a).

In sum, there are far more rights enhancements than downgrades in all asylum directives of the second phase of the CEAS. Contrary to the expectations in much of the literature, increased delegation to the EU goes hand in hand with more (rather than fewer) rights for asylum-seekers and refugees in Europe. As Table 1 shows, the Commission and, to a slightly lesser extent, the EP consistently advance more liberal positions compared to both the status quo and those advanced by the institution most strongly connected to national electorates, the Council. This supports our expectation that the Commission has the strongest non-majoritarian characteristics among the three institutions, while the Council is most majoritarian and the EP takes somewhat of a 'middle ground' position between the two. While the Parliament has been demonstrated to adopt more conservative positions during the second phase of the CEAS (Ripoll Servent and Trauner, 2014, pp. 1148-1149), this may be attributed to the fact that it is now a colegislator taking an active part in the negotiations and thus needing to compromise with the Council to promote their positions on various issues. In consultation procedure, it could only make itself heard by adopting extreme positions that could clearly be identified as coming from the EP. As it is not a co-legislator, the Commission took the 
role of the visionary in the second phase of the CEAS and suggested comparatively progressive policies on the recast Procedures Directive, the recast Reception Conditions Directive, and the Dublin III Regulation. Yet, as all these proposals were considered too progressive by some Member States in the Council (Interview, PermRep\#1; Interview, PermRep\#2; Interview, PermRep\#3; Interview, PermRep\#4), it had to revise them.

Hence, while neither the Commission nor the EP always get their maximum positions into EU legislation, their original positions are usually more liberal than the status quo and, as we will show later, they are able to draw legislative output more effectively towards their preferred output in the second phase of the CEAS.

Some scholars have questioned the significance of these changes and referred to them as “changes of secondary order" (Ripoll Servent and Trauner, 2014, p. 1153). Yet, while EU standards could certainly be higher and retain the focus on controlling the immigration of asylum-seekers (Ripoll Servent and Trauner, 2014, p. 1142), these changes lead to important rights enhancements for asylum-seekers and refugees in several EU Member States. For example, some Member States employed detention as a general practice for new asylum-seekers. In Malta, asylum-seekers were detained as a matter of course, which under the new EU provisions is no longer possible (Interview, PermRep\#2). Earlier labour market access in Germany and France can potentially improve the integration of asylum-seekers that were denied it previously. The internal protection alternative is often used to provide applicants with a 'leave to remain' but to deny them an actual status, even where they could not be returned due to technical obstacles.

$<$ Insert Table 1 about here >




\section{The agenda-setting powers of the Commission and the European Courts}

In this section, we will explain raised standards through the enhanced agenda-setting powers of non-majoritarian institutions. Although they are interlinked, we distinguish two types of agendasetting. The first type is the Commission's agenda-setting through its right of initiative. As suggested earlier, the Commission's agenda-setting powers are enhanced under qualified majority vote in the Council, because Member States can be outvoted and the Commission proposal does not need to accommodate all outliers but can instead set a course. The second type of agendasetting powers relates to the judicial review of the CJEU. If the CJEU rules that a national practice is out of line with EU law, a need for further EU legislation is created, closing potential gaps in the already existing instruments. Additionally, the increased 'juridification' (Kaunert and Léonard, 2012) has enhanced the competences of the ECtHR, which has already drawn on EU legislation to substantiate its argumentation (see the judgment MSS vs. Belgium and Greece, ECtHR, 2011). In the following section, we will illustrate the two types of enhanced agendasetting powers, using the examples of access to work and detention from the Reception Conditions Directive.

\section{Access to work}

Access to work was considered one of the most controversial issues from the very beginning of the negotiations. It was among the most contested issues in the first and the second phase of the CEAS. Some Member States (e.g. France and Germany) feared that an early labour market access could be a pull-factor that would increase the number of applicants. Other Member States (e.g. Sweden and the Netherlands) and the Commission argued that early access would help to integrate asylum-seekers and alleviate pressures on national welfare systems (Council of Ministers, 2000b: 2; Interview, PermRep\#3; Interview, PermRep\#4).

In the original directive, access to work was granted after one year. The recast directive provides it after nine months. This is more liberal than the standard provided in two traditionally strong Member States, Germany and France. These Member States favoured late access to work in order to send a signal both to potential asylum-seekers and the electorate (Interview, Consultant) and had blocked any attempts of the Commission and other Member States to introduce earlier access in the original Reception Conditions Directive (Zaun, 2016, p. 145-146). The higher protection standard provided by the recast directive can be explained through the enhanced role of non-majoritarian institutions. 
Debates on the recast Reception Conditions Directive were initiated by the Commission and were based on the implementation studies of the Commission, NGOs, and groups of legal experts which highlighted gaps and inconsistencies in implementation resulting from ambiguous wording in the directives. As access to work was, again, considered a core issue in the directive, the Commission dedicated a whole paragraph to it in the introduction, elaborating why access should be granted after six months - six months earlier than in the original Reception Conditions Directive (European Commission, 2008, p. 5).

With the qualified majority vote in the Council, the Commission's agenda-setting power was enhanced and Germany and France, the only Member States to oppose access to work earlier than twelve months, could no longer block it. The nine months laid down in the directive represent a compromise between the Commission's position to have it after six months (European Commission, 2008, p. 24) and these two restrictive Member States (Council of Ministers, 2012, p. 39). Initially the EP sided with the Commission, advancing labour market access after six months (European Parliament, 2009). Eventually, however, the EP and the Council met in the middle and agreed on a maximum-period of nine months. At the same time the EP accepted the Council's demand to keep most of the existing conditions, e.g. asylumseekers will only have access to the labour market if no decision has been taken on their claim within the period of nine months (Peers, 2012, p. 5).

\section{Detention}

The practice of detaining asylum-seekers during the application procedures has always been criticized by NGOs (ECRE, 1996). However, Member States sought to keep tight control of this issue during the first phase of the CEAS. The original Reception Conditions Directive does not define the conditions under which Member States may or may not detain asylum-seekers. The recast directive introduces an article proposing that only a limited number of detention grounds are valid (art. 8). The five exclusive reasons for detention are (a) verification of identity, (b) determination of elements which can only be obtained through detention (e.g. in case of a risk of absconding), (c) related to a decision on the right to enter the territory in an asylum procedure, (d) in case of repeat applications submitted by applicants who try to circumvent detention for return/extradition, (e) when protection of national security or public order so requires. Moreover, asylum-seekers shall not be detained for the sole reason that they apply for asylum (para. 1) and detention is conditional in the individual assessment of each case (para. 2). This article was inserted "taking into consideration the wide use of detention for asylum-seekers by 
Member States and the developing case law of the European Court of Human Rights" (European Commission, 2008, p. 6). The case law referred to by the Commission is that of Saadi v. the United Kingdom (ECtHR, 2008). In this case the dissenting vote of six judges held that art. 18 para. 1 of the Procedures Directive should be considered an adjunct to the rules set in art. 7 of the reception conditions directive. Thus, "Member States shall not hold a person in detention for the sole reason that he/she is an applicant for asylum". The Commission makes the same link between the procedures directive and the reception conditions directive in their legislative proposal. This is reflected in para. 1 of the article.

The provision that detention should be made conditional on the individual assessment of a case goes back to Recommendation $\operatorname{Rec}(2003) 5$ of the Committee of Ministers to Member States on measures of detention of asylum-seekers. According to paragraph 4 of this recommendation, "[m] easures of detention of asylum-seekers should be applied only after a careful examination of their necessity in each individual case". According to the recommendation detention is lawful "when protection of national security and public order so requires" which made its way into para. 2 lit. e.

Para. 2 lit. $\mathrm{c}$ is an exception which was already confirmed by most ECtHR judges (eleven) in the case of Saadi v. the United Kingdom. According to them the practice of the UK to detain applicants to accelerate the asylum procedure did not violate art. 5 para. $1 \mathrm{ECHR}$ (right to liberty and security), as each state has the right to decide to whom it grants access to its territory (para. 65).

Following Conclusion No. 44 of the Executive Committee of the UNHCR Programme, the UNHCR's Guidelines, and the Committee of Ministers' Recommendation, detention of asylumseekers is lawful under certain circumstances, e.g. while identity checks are taking place, when elements comprising the asylum claim need to be determined or when public order requires. This is reflected in para. 2 lit. a, b and e.

Four out of these five grounds for detention were already part of the Commission proposal (European Commission, 2008, p. 20). Only one ground was added by the Council, which stated in lit. $\mathrm{d}$ that applicants can be detained for purposes of expulsion if the Member States can show that the person concerned only applied for asylum to delay the procedure.

Some Member States wanted to add additional grounds for detention. One Member State suggested adding a lack of co-operation by the asylum-seeker while another Member State wanted to introduce illegal entry as a ground for detention (Council of Ministers, 2010b, p. 3, 
footnote 6). This likely was Malta, as Malta usually detained asylum-seekers for irregular entry (PermRep\#2). The Commission, however, argued that adding such vague grounds could lead to systematic detention of asylum-seekers (Council of Ministers, 2010b, p. 3, footnote 6). Eventually, the EP convinced the Council to drop apprehension for an irregular stay as a detention ground. The EP and the Commission, moreover, ensured that detention as part of expulsion was limited to cases in which the return directive applied (Peers, 2012, p. 4).

The case of detention shows that the Commission (and the EP) used court rulings as a tool for introducing safeguards for asylum-seekers in detention and to limit the number of detention grounds.

\section{The role of the Commission and the EU Court in holding Member States to account}

Both the Commission and the CJEU had a right to enforce refugees' and asylum-seekers' rights in the implementation phase as well and thus could and did raise standards in policy outcomes. For instance, the Commission could initiate infringement procedures against states for nonimplementation and the courts could assess whether Member States' implementation was in line with EU law.

In the first phase only the Court made use of its right to enforce more effective implementation. While the Commission had initiated an infringement procedure against Greece for nonimplementation of art. 26 of the original Reception Conditions Directive, it did not initiate a single content-related infringement procedure. Yet, there was a wide consensus that a number of Member States, particularly in Southern Europe and some of the new Eastern European Member States, had not correctly transposed the directives, maintaining severe deficiencies in their asylum systems. At the height of the 2015 crisis, the Commission eventually initiated infringement procedures: 40 infringement decisions against Member States were launched in September 2015 for non-implementation of EU legislation and in December 2015 the Commission initiated an infringement procedure against Greece, Croatia, Italy, Malta and Hungary for non-implementation of the CEAS (Carrera et al., 2015, p. 14; European Commission, 2015).

The CJEU, which was often informed by judgement of the European Court of Human Rights (ECtHR), left an even stronger mark on EU legislation. The ECtHR decisions MSS v Belgium and Greece (ECtHR, 2011) and Tarakhel v Switzerland (ECtHR 2014) and the CJEU decision NS vs. Netherlands (CJEU, 2011) have determined the insufficiencies of Southern European asylum systems and demonstrated that these Member States had not fully transposed EU asylum directives. In MSS v Belgium and Greece an Afghan citizen filed an asylum application in 
Belgium after entering through Greece. In line with Dublin II, he was sent back to Greece and detained in degrading conditions, and became homeless upon his release with no access to work or social benefits. The ECtHR suggested that Greece had not transposed the Reception Conditions Directive (and the Procedures Directive) and ruled that Greece's detention and reception conditions violated art. 3 ECHR, which prohibits torture and inhuman and degrading treatment. Moreover, the Court ruled that Greece had violated art. 13 ECHR (right to an effective remedy) in conjunction with art. 3 ECHR. This was due to the deficiencies of the asylum procedure and the risk the claimant faced in being returned to his country of origin without thorough examination of fact and law and access to a legal remedy. Belgium, too, had violated art. 3 ECHR for exposing the applicant to the degrading detention and living conditions in Greece without prior assessment of the situation. It had thus also violated art. 13 ECHR in conjunction with art. 3 ECHR, as it did not provide any access to legal remedies in the framework of Dublin transfers. The Court said that "any complaint that expulsion to another country will expose an individual to treatment prohibited by Article 3 of the Convention requires close and rigorous scrutiny and that, subject to a certain margin of appreciation left to the States, conformity with Article 13 requires that the competent body must be able to examine the substance of the complaint and afford proper reparation" (ECtHR, 2011, p. 80-81). Eventually, this ruling led to a de facto suspension of Dublin transfers to Greece. In Tarakhel v Switzerland (ECtHR, 2014) this ruling was confirmed and extended to Italy. This further questioned the legitimacy and practicability of the Dublin system. Shortly after MSS v Belgium and Greece, the CJEU (2011) ruled in NS v UK and ME and others $v$ Ireland that a Dublin transfer is not allowed when the transferring Member State "cannot be unaware that systemic deficiencies in the asylum procedure and in the reception conditions of asylum-seekers in that Member State amount to substantial grounds for believing that the asylum seeker would face a real risk of being subjected to inhuman or degrading treatment within the meaning of Article 4 of the [EU] Charter" (paras. 94 and 106). The CJEU judgment is remarkable, as the CJEU to some extent questioned the mutual recognition of asylum decisions under all circumstances and hence fostered a retrenchment in European integration. The CJEU has often been described as strongly pro-integrationist (Burley and Mattli, 1993). Yet, in this case it prioritised the human rights standards laid down in the EU Charter. The adoption of the Charter with the Lisbon Treaty seems to have furthered CJEU's role as a guardian of human rights, even at the expense of EU integration.

\section{Conclusion}


This paper has demonstrated that transferring asylum policies to the EU level does not decrease the number of checks and balances policy-makers are faced with, particularly with the move towards the ordinary legislative procedure. It therefore should not be viewed as an act of restrictive venue-shopping as previously argued by scholars. Instead, the EU level policy-making provides mechanisms that tend to safeguard and strengthen minority rights, even when Member States in the Council have more restrictive preferences. Analyzing EU asylum policy-making from a principal-agent perspective helps to understand why the Commission, the CJEU and the EP -institutions that are more insulated from majoritarian pressures than national governments - have consistently adopted policy positions that are less restrictive than those of the Council. Delegation to supranational institutions strengthens non-majoritarian governance and allows national governments to depoliticize unpopular migration policies. In turn, such delegation helps to safeguard minority rights against populist pressures for greater restrictions. Delegation dynamics can therefore account for the fact that common EU policies go beyond the 'lowest common denominator' and are often less restrictive even than policies found in Member States that are 'strong regulators' (see Zaun 2016).

Two principal objections can be raised with regards to the arguments developed above. First, while the authority and influence of non-majoritarian institutions in policy-making has increased, Member States often remain in the driving seat when it comes to the implementation of EU policies. This can lead to highly heterogeneous outcomes across the Member States, which can make a mockery of new safeguards and new rights agreed to at the EU level. While we have recently been able to observe a greater ability by the Commission and the CJEU to hold Member States accountable over implementation, it is important to acknowledge that strengthened standards on paper are only a necessary but not a sufficient condition for greater safeguards on the ground. However, recent Commission proposals to transform some of the EU's core asylum directives into regulations to reduce Member State discretion (European Commission 2016a, 2016b) and initiatives to delegate greater authority to the European Asylum Support Office (Commission 2016c) over national implementation measures, are steps to promote better compliance and enforceability of commitments. Second, one might argue that the EU's response to the Syrian crisis poses a challenge to our central claims, pointing to the highly restrictive nature of the EU-Turkey Statement (European Commission 2016d) and the limitations of the EU's emergency response legislation, particularly with regard to relocation.

However, we argue that these recent initiatives in fact strengthen our overall argument. What characterises EU agreements during a crisis is the severely limited involvement of supranational EU institutions and their reversion to more intergovernmental governance (see parallels with the 
Eurocrisis as discussed by Puetter, 2014 or Bickerton et al., 2015). The EU-Turkey Statement, an intergovernmental agreement, is a case in point. The CJEU recently declared that neither the European Council nor any other institution of the EU was party of the agreement and therefore had no jurisdiction over it (CJEU2017). With regard to the heavily criticized emergency legislation on quota-based relocation (Council of Ministers 2015a, Council of Ministers 2015b), it is important to note that in adopting these 'responsibility-sharing' measures, Member States have decided to bypass the ordinary legislative procedure and instead base such legislation on Article 78(3) (TFEU), which explicitly reverts the role of the European Parliament back to 'consultation only'. It could be argued that this was done to speed up the legislation when a fast response was needed. But perhaps more importantly, it should act as reminder that Member States have generally been much more reluctant to delegate redistributive issues to supranational institutions while being more willing to delegate on regulatory matters (Majone 1996).

Overall, the EU's response to the crisis therefore strengthens our claim that the delegation to supranational, non-majoritarian, institutions strengthens minority rights in Europe. It also suggests that the greatest long-term impact of the EU in strengthening refugee protection should be expected to stem from the continuation of an incremental regulatory approach embedded in strong non-majoritarian governance dynamics and is unlikely to result from highly politicized intergovernmental bargains. While delegation strengthens minority rights and shields them from the preferences of latently anti-immigrant majorities, it is not unproblematic, as it may also further voters' estrangement from both national and European politics. It may also reinforce the perception that political elites are detached from the worries and demands of their voters. This in turn has recently been shown to strengthen right-wing populism and Euroscepticism across Europe.

\section{Bibliography}

Alonso, S. and Claro da Fonseca, S. (2012) 'Immigration, Left and Right'. Party Politics, Vol. 18, No. 6, pp. 865-884.

Bickerton, C. J., Hodson, D., and Puetter, U. (2015) 'The new intergovernmentalism: European integration in the post-Maastricht era.' Journal of Common Market Studies, Vol. 53, No. 4, pp. 703722.

Burley, A.-M. and Mattli, W. (1993) 'Europe before the court: A political theory of legal integration.' International Organization, Vol. 47, No. 1, pp. 41-76.

Carrera, S., Blockmans, S., Gros, Daniel and Guild, E. (2015) The EU's response to the Refugee Crisis: Taking stock and setting policy priorities, 16 December. Available at «https://www.ceps.eu/system/files/EU\%20Response $\% 20$ to $\% 20$ the $\% 202015 \% 20$ Refugee $\% 20 \mathrm{C}$ risis_0.pdf» Accessed 28 June 2016. 
CJEU (2011) NS and others v Secretary of State for the Home Department and M.E.and others $\mathrm{v}$ Refugee Applications Commissioner and Minister for Justice, Equality and Law Reform (Joined Cases C-411/10 and C-493/10). Available at «http://eur-lex.europa.eu/legalcontent/EN/TXT/PDF/?uri=CELEX:62010CJ0411\&from=EN» (accessed 28 October 2016).

CJEU (2017) The General Court declares that it lacks jurisdiction to hear and determine the actions brought by three asylum-seekers against the EU-Turkey statement which seeks to resolve the migration crisis, General Court of the European Union PRESS RELEASE No 19/17 Luxembourg, 28 February 2017. Available at «https://curia.europa.eu/jcms/upload/docs/application/pdf/2017-02/cp170019en.pdf» (accessed 25 May 2017).

Council of Ministers (2000a) Note from the French Delegation to the Asylum Working Party on 'Conditions for the Reception of Asylum-Seekers, 23 June. Available at «http://data.consilium.europa.eu/doc/document/ST-9703-2000-INIT/en/pdf» (accessed 19 March 2015).

Council of Ministers (2000b) Outcome of Proceedings by the Asylum Working Party on the conditions for the reception of asylum-seekers, 12 July. Available at: «http:// register.consilium.europa.eu/ doc/srv?l=EN\&f=ST\%2010242\%202000\%20INIT» (accessed 2 May 2016).

Council of Ministers (2010a) Note from the Presidency to the Strategic Committee on Immigration, Frontiers and Asylum on the Common European Asylum System (state of play/ certain issues), 26 April. Available at «http://register.consilium.europa.eu/doc/srv?l=EN\&f=ST\%208777\%202010\%20INIT» (accessed 6 May 2016).

Council of Ministers (2010b) Outcome of Proceedings by the Asylum Working Party on the proposal for a recast directive of the European Parliament and of the Council laying down minimum standards for the reception of asylum-seekers, 25 October. Available at «http://register.consilium.europa.eu/doc/srv?l=EN\&f=ST\%2015119\%202010\%20INIT» (accessed 6 May 2016).

Council of Ministers (2012) Item note from the General Secretariat of the Council to the Permanent Representatives Committee (Part II) and to the Council on the first reading of the amended proposal for the recast directive of the European Parliament and of the Council laying down minimum standards for the reception of asylum-seekers (concerning a political agreement), 27 September. Available

at «http://register.consilium.europa.eu/doc/srv?l=EN\&f=ST\%2014112\%202012 \%20REV\%201» Accessed 6 May 2014.

Council of Ministers (2015a): Council of the European Union, Council Decision (EU) 2015/1523 of 14 September 2015 establishing provisional measures in the area of international protection for the benefit of Italy and of Greece', OJ L 239, 15.9.2015, pp. 146-156.

Council of Ministers (2015b): Council Decision (EU) 2015/1601 of 22 September 2015 establishing provisional measures in the area of international protection for the benefit of Italy and Greece. OJ L 248, 24.9.2015, pp. 80-94.

Dathan, M. (2016) Nigel Farage in Racism Storm over Brexit Refugee Posters, Daily Mail, 16 June 2016.

ECRE (1996) ECRE summary of key recommendations on the detention of asylum-seekers. Available at «http://www.ecre.org/component/downloads/downloads/82.html» Accessed 6 May 2014. 
El-Enany, N. and Thielemann, E. (2011) 'The Impact of the EU on National Asylum Policies.' In Wolff, S., de Zwaan, J. and Goudappel, F. The Area of Freedom, Security and Justice: myth or reality? Taking stock of the Lisbon Treaty and the Stockholm Programme (The Hague: TMC Asser Press), pp. $97-$ 116.

European Commission (2008) Proposal for the recast directive of the European Parliament and of the Council laying down minimum standards for the reception of asylum-seekers, 3 December. Available at uhttp://eurlex.europa.eu/LexUriServ/LexUriServ.do?uri=COM:2008:0815:FIN:EN:PDF» (accessed 6 May 2016).

European Commission (2015) Implementing the Common European Asylum System: Commission escalates 8 infringement proceedings, 10 December. Available at " http://www.statewatch.org/news/2015/dec/eu-com-infringements-10-12-15.pdf» Accessed 28 June 1016.

European Commission (2016a): Proposal for a regulation of the European Council and of the Council on standards for the qualification of third-country nationals or stateless persons as beneficiaries of international protection, for a uniform status for refugees or for persons eligible for subsidiary protection and for the content of the protection granted and amending Council Directive 2003/109/EC of 25 November 2003 concerning the status of third-country nationals who are long-term residents. 13 July. Available at «https://ec.europa.eu/homeaffairs/sites/homeaffairs/files/what-we-do/policies/european-agenda-migration/proposalimplementation-

package/docs/20160713/proposal_on_beneficiaries_of_international_protection__subsidiary_protection_eligibility_-_protection_granted_en.pdf»(accessed 24 May 2017).

European Commission (2016b): Proposal for a regulation of the European Parliament and of the Council establishing a common procedure for international protection in the Union and repealing Directive 2013/32/EU. 13 July. Available at «https:/ / ec.europa.eu/homeaffairs/sites/homeaffairs/files/what-we-do/policies/european-agenda-migration/proposalimplementation-

package/docs/20160713/proposal_for_a_common_procedure_for_international_protection_in _the_union_en.pdfy (accessed 24 May 2017).

European Commission (2016c): Proposal for a Regulation of the European Parliament and of the Council on the European Union Agency for Asylum and repealing Regulation (EU) No 439/2010. 4 May. Available at « https://ec.europa.eu/home-

affairs/sites/homeaffairs/files/what-we-do/policies/european-agenda-migration/proposalimplementation-package/docs/20160504/easo_proposal_en.pdf» (accessed 24 May 2017).

European Commission (2016d): EU-Turkey Statement: Questions and Answers. Brussels, 19 March. Available at « http://europa.eu/rapid/press-release MEMO-16-963 de.htm» (accessed 25 May 2017). ECtHR (2008) Case of Saadi v United Kingdom (Application No. 13229/03). 29 January 2008. Available at «http://www.refworld.org/docid/47a074302.html» (accessed 28 October 2016).

ECtHR (2011) Case of MSS v Belgium and Greece (Application No. 30696/09). 21 January 2011. Available at «https://www.escrnet.org/sites/default/files/CASE\%20OF\%20M.S.S.\%20v.\%20BELGIUM\%20AND\%20GREE CE.pdf» (accessed 21 August 2016).

ECtHR (2014) Case of Tarakhel v Switzerland (Application No. 29217/12). 4 November 2014. Available 
«http://www.asylumlawdatabase.eu/sites/www.asylumlawdatabase.eu/files/aldfiles/CASE\%20 OF\%20TARAKHEL\%20v.\%20SWITZERLAND.pdf».

European Parliament (2009) European Parliament legislative resolution of 7 May 2009 on the proposal for a directive of the European Parliament and of the Council laying down minimum standards for the reception of asylum-seekers (recast), 7 May. Available at «http://www.europarl.europa.eu/sides/getDoc.do?type $=$ TA\&language $=$ EN\&reference $=$ P6TA-2009-376» Accessed 6 May 2016.

Fry, J.D. (2005) 'European asylum law: race-to-the-bottom harmonization?' Journal of Transnational Law \& Policy, Vol. 15, No. 1, pp. 97-108.

Guiraudon, V. (2000) 'European Integration and Migration Policy: Vertical Policy-Making as Venue Shopping'. Journal of Common Market Studies, Vol. 38, No. 2, pp. 251-271.

Hathaway, J. (2003) 'What's in a Label?' European Journal of Migration and Law, Vol. 5, No. 1, pp. 1-21.

House of Lords European Union Committee (2008) 'The Treaty of Lisbon: an impact assessment. Volume I: Report' $10^{\text {th }}$ Report of Session 2007-08'. London: The Stationery Office Limited.

Howard, M.M. (2010) 'The Impact of the Far-Right on Citizenship Policy in Europe: Explaining Continuity and Change'. Journal of Ethinic and Migration Studies, Vol. 36, No. 5, pp. 735-751 .

Jacobs, F. G. (2003) 'Judicial Dialogue and Cross-Fertilization of Legal Systems: The European Court of Justice'. Texas International Law Journal, Vol. 38, No. 3, pp. 547-556.

Joppke, C. (2001) 'The Legal-Domestic Sources of Immigrants Rights: the United States, Germany and the European Union.' Comparative Political Studies, Vol. 34, No. 4, pp. 339-366.

Kaunert, C. (2009) 'Liberty versus Security? EU Asylum Policy and the European Commission'. Journal of Contemporary European Research, Vol. 5, No. 2, pp. 148-170.

Kaunert, C. (2010) European Internal Security: towards supranational governance in the area of freedom, security and justice, (Manchester: Manchester University Press).

Kaunert, C. and Léonard, S. (2012) 'The Development of the EU Asylum Policy: Venue shopping in Perspective'. Journal of European Public Policy, Vol. 19, No. 9, pp. 1396-1413.

Majone, G. (1996) 'The European Commission as regulator'. In: Majone, G. (ed.) Regulating Europe (London and New York: Routledge), pp. 61-79.

Marquand, D. (1979) Parliament for Europe (London: Jonathan Cape).

Peers, S. (2012) The EU directive on reception conditions: A weak compromise', Statewatch Analysis. Available at «http://www.statewatch.org/analyses/no-184-reception-compromise.pdf» Accessed 2 May 2016.

Pollack, M.A. (1997) 'Delegation, agency, and agenda-setting in the European Community'. International Organization, Vol. 51, No. 1, pp. 99-134.

Puetter, U. (2014). The European Council and the Council: New intergovernmentalism and institutional change (Oxford: Oxford University Press).

Ripoll Servent, A. and Trauner, F. (2014) 'Do supranational EU institutions make a difference? EU asylum law before and after "communitarisation". Journal of European Public Policy, Vol. 21, No. 8, pp. 1142-1162.

Rydgren, J. (2004) 'Explaining the Emergence of Radical Right-Wing Populist Parties: The Case of Denmark'. West European Politics, Vol. 27, No. 3, pp. 474-502. 
Seawright, J. and Gerring, J. (2008) 'Case Selection Techniques in Case Study Research'. Political Research Quarterly, Vol. 61, No. 2, pp. 294-308.

Stetter, S. (2000) 'Regulating Migration: Authority Delegation in Justice and Home Affairs.' Journal of European Public Policy, Vol. 7, No. 1, pp. 80-103.

Suhrke, A. (1998) 'Burden-Sharing During Refugee Emergencies: The Logic of Collective versus National Action.' Journal of Refugee Studies, Vol. 11, No. 4, pp. 396-415.

Thatcher, M. and Stone Sweet, A. (2002) 'Theory and Practice of Delegation to non-majoritarian institutions.' West European politics, Vol. 25, No. 1, pp. 1-22.

Thielemann, E. and El-Enany, N. (2013) 'Refugee Protection as a Collective Action Problem: Is the EU Shirking its Responsibilities.' European Security, Vol. 19, No. 2, pp. 209-229.

Thielemann, E. (2006) 'The Effectiveness of Governments' Attempts to Control Unwanted Migration.' In Parsons, C. and Smeeding, T. (eds.) Immigration and the Transformation of Europe (Cambridge: Cambridge University Press), pp. 442-472.

Zaun, N. (2016) 'Why EU Asylum Standards Exceed the Lowest Common Denominator'. Journal of European Public Policy, Vol. 23, No. 1, pp. 136-154.

Zaun, N. (2017) EU Asylum Policies. The Power of Strong Regulating States (Houndmills: Palgrave Macmillan).

\section{List of interviewees}

Consultant Expert interview with freelance consultant on EU asylum policies, $24 / 3 / 2013$

PermRep\#1 Expert Interview conducted with the Permanent Representation of Germany, 22/11/2012.

PermRep\#2 Expert Interview conducted with the Permanent Representation of Malta, 16/4/2012.

PermRep\#3 Expert Interview conducted with the Permanent Representation of the Netherlands, 3/4/2012.

PermRep\#4 Expert Interview conducted with the Permanent Representation of Sweden, 29/3/2012. 
Table 1: Positions of the three legislative institutions on key issues (relative to status quo ante) and outcome of final agreement (relative to status quo ante)

\begin{tabular}{|c|c|c|c|c|c|}
\hline Directive & Issue & Commission $^{1}$ & European Parliament $^{2}$ & Council $^{3}$ & Final Agreement $^{3}$ \\
\hline \multirow{5}{*}{$\mathrm{RCD}$} & Scope & + & + & 0 & + \\
\hline & Detention (Grounds for) & ++ & ++ & 0 & + \\
\hline & Access to work & ++ & ++ & 0 & + \\
\hline & Access to material reception conditions & ++ & + & 0 & + \\
\hline & Vulnerable applicants with special reception needs & ++ & ++ & 0 & + \\
\hline \multirow{5}{*}{ QD } & Family definition & ++ & + & 0 & + \\
\hline & Definition of actors of protection & + & + & - & + \\
\hline & Internal Protection Alternative & + & + & 0 & + \\
\hline & Rights of beneficiaries of subsidiary protection & ++ & + & 0 & + \\
\hline & Gender-related persecution & + & + & + & + \\
\hline \multirow{5}{*}{$\mathrm{APD}$} & Access to procedure & + & + & 0 & + \\
\hline & Rights related to personal interview & + & + & 0 & $+/-$ \\
\hline & Free legal information at $1^{\text {st }}$ instance & ++ & ++ & 0 & + \\
\hline & Right to remain in case of subsequent applications & - & - & - & - \\
\hline & Right to an effective remedy & + & + & 0 & + \\
\hline Key: & \multicolumn{5}{|c|}{$\begin{array}{l}+ \text { stronger safeguards and/or more rights compared to status quo } \\
++ \text { stronger safeguards as compared to the other institutions on this specific issue; yet, this does not imply safeguards twice as high as }+ \\
\text { - weakened safeguards and/or reduced rights } \\
0 \text { reflecting status quo }\end{array}$} \\
\hline Notes: & \multicolumn{5}{|c|}{$\begin{array}{l}{ }^{1} \text { The Commission's position is based on the (first) recast proposal submitted by the Commission. } \\
{ }^{2} \text { The European Parliament's position is based on its amendments on the (first) recast Commission proposal. } \\
{ }^{3} \text { The Council's position is based on reactions by Member States lowest common denominator in the Council working groups at their first meeting subsequent } \\
\text { to the submission of the Commission proposal. } \\
{ }^{4} \text { The assessment of the final agreements is based on the recast directives and evaluations of ECRE about the main changes. We follow ECREs interpretation } \\
\text { regarding rights-enhancing and rights-reducing legislative output. }\end{array}$} \\
\hline
\end{tabular}


